\title{
Porozumienie towarzystw regionalnych z Gliwic i Zduńskiej Woli. Przykład dobrej praktyki ( $z$ teorią $w$ tle)
}

\author{
Agreement of Regional Societies from Cliwice \\ and Zduńska Wola. A Case of Good Practice \\ (with the Theory Behind)
}

Prezentowane tu refleksje zostały zainspirowane porozumieniem zawartym pomiędzy dwiema organizacjami regionalistycznymi - Stowarzyszeniem Przyjaciół Ziemi Gliwickiej i Towarzystwem Przyjaciół Zduńskiej Woli. Dokument został podpisany 5 X 2019 r. w Gliwicach, zaś jego treść prezentujemy - in extenso - poniżej. Zapewne nie jest to ani pierwsze, ani jedyne porozumienie tego rodzaju. Poza tym wiele stowarzyszeń współpracuje nieformalnie, szczególnie w warunkach lokalnych wspierając się w rozmaity sposób, realizując wspólnie różnorodne inicjatywy. Regionalne towarzystwa kultury (miłośnicze, artystyczne, pasjonackie, edukacyjne, naukowe i inne) mają z reguły spore doświadczenia także we współpracy z instytucjami samorządowymi. Charakterystyczne są w tym kontekście relacje między stowarzyszeniami a szkołami, domami kultury, archiwami, szczególnie zaś z placówkami muzealnymi ${ }^{x}$.

Tytułowe porozumienie wydaje się jednak posiadać szczególny charakter, jako że zawarte zostało między stowarzyszeniami skupiającymi miłośników regionów znacznie oddalonych od siebie. Warto to podkreślić, zwracając uwagę, że „usieciowienie” aktywności regionalistycznej może z powodzeniem wykraczać poza granice powiatu czy też województwa, przyczyniając się tym samym do budowania poczucia wspólnoty ruchu w wymiarze ogólnopolskim.

I Por. K. Barańska, Muzea i organizacjepozarządowe. Wposzukiwaniu dobra wspólnego, „Rocznik Muzeum Wsi Mazowieckiej w Sierpcu” 2017, t. viII, s. 6-I3. 


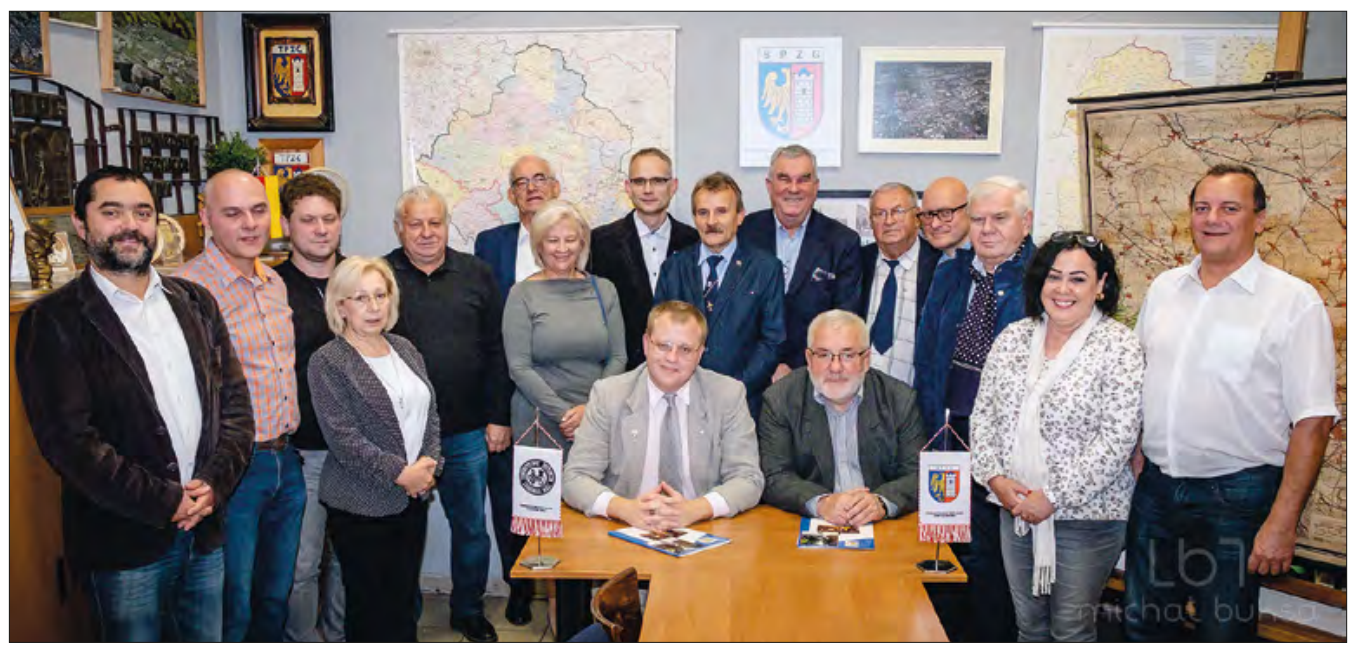

FOT. 1 Uroczystość podpisania porozumienia o współpracy towarzystw regionalnych w Gliwicach i Zduńskiej Woli, Gliwice 5 X 2019 (fot. M. Buksa)

Stowarzyszenie Przyjaciół Ziemi Gliwickiej zostało założone w 196r r. jako Towarzystwo MiłośnikówZiemiGliwickiej. Obecniezrzesza ok.200członków działających w I3. Komisjach - Zespołach Programowych, m.in. modelarzy, plastyków, historyków, rzeźbiarzy przestrzennych. W orbicie zainteresowań tutejszych regionalistów sporo miejsca zajmuje zagadnienie wielokulturowości Śląska. Stowarzyszenie jest wydawcą redagowanych na wysokim poziomie „Zeszytów Gliwickich” (w latach 1963-2020 ukazało się 40 tomów).

Towarzystwo Przyjaciół Zduńskiej Woli jest nieco młodsze. Powstało w 1975 r. Zrzesza ok. Ioo członków. To organizacja otwarta na ludzi zainteresowanych nie tylko przeszłością regionu. Świadczy o tym powołana w ostatnich latach Sekcja Miłośników Motoryzacji. Stosunkowo młodą, ale cieszącą się dużym zainteresowaniem w Zduńskiej Woli inicjatywą jest plenerowa impreza edukacyjna „Miasteczko Złotnickiego”. Towarzystwo popularyzuje zagadnienia regionalne, prowadząc także aktywną działalność wydawniczą i wystawienniczą².

Wiele o potrzebie współpracy w nurcie aktywności regionalistycznej już napisano3. Współpraca (dobre praktyki i doświadczenia w tym zakresie,

2 Por.J. Stulczewski, Wspótczesna dziatalność Towarzystwa Przyjaciót Zduńskiej Woli-wyzwania i problemy na wybranych przyktadach, [w:] Blisko i daleko. Sympozjum regionalistów - Praszka 2018 , red. Z. Szczerbik, Z. Włodarczyk, Wieluń-Praszka 2019, s. I3I-I47.

3 Kilka referatów poświęcono temu zagadnieniu podczas X. Kongresu Regionalnych Towarzystw Kultury w Bydgoszczy w 2014 r. M.in.: C. Obracht-Prondzyński, Cóż regionalistom po samorząach i na cóż w samorządach regionaliści? Rzecz o związkach oczywistych, koniecznych izazwyczaj trudnych, [w:] Regionalizm polski 25 lat po transformacji jako ważne źródto odrodzenia 
jak też utyskiwania na jej brak) jest jednym z wiodących tematów dyskusji prowadzonych w trakcie organizowanych co cztery lata kongresów regionalnych towarzystw kultury4. Dlaczego współpraca stowarzyszeń regionalnych z innymi organizacjami społecznymi, instytucjami samorządowymi, a także sektorem prywatnym jest tak ważna, a postulat kooperacji pozostanie zawsze aktualny?

Po pierwsze, organizacje regionalistyczne, podobnie jak inne podmioty trzeciego sektora, borykają się z rozlicznymi problemami, które obniżają walory całego ruchu. Zalicza się do nich m.in. brak lub słaby przepływ informacji między stowarzyszeniami, niedostateczną współpracę z mediami, częste zatargi z instytucjami sektora publicznego, brak wspólnie akceptowanej i prezentowanej wizji ruchu, słaby zasięg platform, federacji i innych organizacji parasolowych 5 . Te wypunktowane kilkanaście lat temu niedomagania, może w nie tak wielkim stopniu jak wówczas, ale nadal mają wpływ na aktywność i skuteczność działań regionalistycznych pod szyldem stowarzyszeniowym.

Po drugie, współpraca międzystowarzyszeniowa wiąże się z pewnymi ogólnospołecznymi, ale i wewnątrzśrodowiskowymi zobowiązaniami. Hasło współpracy jest zawarte w ideach społeczeństwa obywatelskiego i solidarności. Andrzej Siciński w sposób następujący wypowiadał się na temat misji, jaką mają do spełnienia regionalne towarzystwa kultury: „Niezbędne jest, aby ruch regionalistyczny był świadom tego, że jest jednym z filarów społeczeństwa obywatelskiego, a równocześnie, aby był świadom istnienia i działalności innych elementów tego społeczeństwa, w szczególności najróżniejszego typu tzw. organizacji pozarządowych”. W Wefinicjach społeczeństwa obywatelskiego - owego „świętego Graala” współczesnych dyskusji o stanie demokracji w Polsce i kondycji naszego społeczeństwa - mowa

narodu i państwa. x Kongres Stowarzyszeń Regionalnych w Bydgoszczy. Referaty i prezentacje. Bydgoszcz II-13 września 2014 roku, red. J. Derenda, Bydgoszcz 20I4, s. 20I-210; M. Zdończyk, Eksperyment bydgoski-partycypacja spoteczna w procesach zarządzania bydgoskąkultura, tamże, s. 219-225. W prezentowanych tu diagnozach i postulatach wykorzystano fragmenty referatu wygłoszonego przez autora podczas kolejnego - XI. Kongresu Stowarzyszeń Regionalnych zorganizowanego w Legnicy w dniach 23-25 IX $2018 \mathrm{r}$. (materiały w druku).

4 Wypowiedzi te w przypadku kongresu bydgoskiego zgromadzono w osobnym tomie: Regionalizm polski 25 lat po transformacji jako ważne źródto odrodzenia narodu i państwa. Sprawozdania, wnioski, dokumenty, relacje w mediach, red. J. Derenda, Bydgoszcz 2015.

5 Z. Woźniak, Między rywalizacjąa partnerstwem. Bariery wspótpracy wtadz publicznych zorganizacjami pozarządowymi, [w:] Samoorganizacja spoteczeństwa polskiego: trzeci sektor i wspólnoty lokalnew jednoczącej się Polsce, red. P. Gliński, B. Lewenstein, A. Siciński, Warszawa 2002, s. II6.

6 A. Siciński, Rola stowarzyszeń regionalnych w budowaniu spoteczeństwa obywatelskiego, [w:] Być narodowi pożytecznym. Dokumentacja VII Kongresu Regionalnych Towarzystw Kultury oraz Pierwszego Walnego Zgromadzenia Ruchu Stowarzyszeń Regionalnych Rzeczypospolitej Polskiej, red. A.J. Omelaniuk, Gorzów Wielkopolski-Wrocław 2002, s. 62, przypis I. 
jest wprost o działaniach kolektywnych, a zatem wymagających współpracy. „Nowoczesne społeczeństwo obywatelskie to [...] społeczeństwo, w którym demokrację proceduralną uzupełnia partycypacja i zaangażowanie jednostki w działania kolektywne" - oto fragment jednej z nich7. Wprawdzie nie wiemy, jaką formę przyjmą społeczeństwa przyszłości i czy model typu obywatelskiego będzie nadal postulowanym i adekwatnym wobec problemów naszego świata, jednak polaryzacja postaw światopoglądowych i wszechogarniający niepokój o przyszłość czyni postulaty obywatelskości nadal aktualnymi. Wiąże się z tym pojęcie kapitału społecznego, które jest kolejnym obowiązkowym motywem współczesnych dyskusji nad przemianami społeczno-kulturowymi ${ }^{8}$.

Skoro już mowa o wewnątrzśrodowiskowych zobowiązaniach, które nakazują niejako regionalistom traktować współpracę nie tylko okazjonalnie, to przypomnijmy, że jest o niej mowa (implicite) w kluczowym dokumencie, jakim jest Karta Regionalizmu Polskiego. Jeśli regionaliści nadal traktują ten dokument poważnie, a zawarte w nim treści uznają za aktualne, są niejako zobowiązani do solidarności, którą trudno sobie wyobrazić bez współpracy. Innym zapisem, który warto przywołać, jest Karta Zasad Działania Organizacji Pozarządowej przyjęta na I Ogólnopolskim Forum Inicjatyw Pozarządowych we wrześniu I 997 r. Czytamy w niej, że: „Organizacje pozarządowe współpracują ze sobą na zasadach partnerstwa i wzajemnego wspierania się w swoich działaniach. W sytuacjach, gdy zachodzi konflikt uznawanych wartości, organizacje podejmują działania przy zachowaniu zasad tolerancji i uznania prawa innych do posiadania odmiennego zdania"9. Zwróćmy uwagę, że nie ma tu mowy o współdziałaniu jako zasadzie, a raczej o zasadach współdziałania. Zakłada się zatem, że współpraca organizacji jest czymś naturalnym.

Trzecią determinantą kooperacji jest możliwość kompleksowego widzenia spraw lokalnych. Przyjmijmy roboczo założenie, że stowarzyszenia lokalne dzielą się na takie, które szukają inspiracji w miejscowych tradycjach, prowadząc działalność kulturotwórczą (taki charakter mają ulubione stowarzyszenia regionalistów, czyli miłośnicze), oraz takie, które realizują programy lokalnego rozwoju w innych ważnych obszarach - pomocy potrzebującym, ochrony środowiska, promocji zdrowia itp. Regionaliści

7 M. Kalinowski, Idea spoteczeństwa obywatelskiego a rozwój regionalny, [w:] Rozwój regionalny - konsekwencje integracji, red. A.F. Bocian, Białystok 2005, s. 228.

8 Por. Z. Zagała, Kapitat spoteczny w teorii i praktyce. Więcej pytań niż odpowiedzi, [w:] Kapitat spoteczny, partycypacja spoteczna, rozwój lokalny, red. E. Psyk-Piotrowska, Łódź 2009, s. II-I3.

9 Dokument przytacza w całości J. Lichwiarz, Etyka $w$ dziatalności organizacji pozarządowych, „Annales. Etyka w Życiu Gospodarczym” 2011, vol. I4, nr 2, s. 107-108. 
zainteresowani są przeszłością, żyją przeszłością, prowadzą akcje upamiętniania miejsc, wydarzeń i postaci, gromadzą i archiwizują pamiątki. Wiąże się z tym też pewien problem stereotypizacji, w wyniku której regionalista postrzegany jest jako ktoś raczej oderwany od bieżącej rzeczywistości, a już tym bardziej niemyślący o przyszłości. Ważne więc, aby środowiska promujące rozwój konkretnych społeczności lokalnych i środowiska pielęgnujące tradycje tych społeczności, pozostawały ze sobą w twórczym kontakcie. NGO-sy - naśladując akcje prowadzone w innych społecznościach lokalnych, a czasami przeszczepiając do małych środowisk pomysły realizowane w metropoliach, w kompletnym oderwaniu nie tylko od tradycji pojmowanych czysto historycznie, ale też właściwie bez uwzględnienia lokalnej specyfiki, która zawsze stanowi pewne kontinuum - też na takim aliansie zyskają. Szczególnie cenna wydaje się współpraca towarzystw statutowo regionalistycznych oraz takich, które podobnych zapisów w statutach nie mają, ale również bliskie jest im poszanowanie przeszłości. Dobrze znany jest przykład grup rekonstrukcyjnych. Zwróćmy uwagę, że grupy te pierwotnie nie mają z reguły wpisanego regionalizmu w własną ideologię i statuty (jeśli takowe posiadają), ale stały się znakomitymi sojusznikami i współpracownikami stowarzyszeń regionalistycznych. Regionaliści powinni próbować zarażać inne stowarzyszenia swoją pasją i uświadomić im, że zawsze, cokolwiek stowarzyszenia by nie robiły, osadzone są w jakimś miejscu - czy to gmina wiejska, czy centrum Warszawy. Rolę inspirująco-inicjatorską, właśnie w oparciu o kooperację i współpracę, przewiduje dla towarzystw regionalnych część badaczy ${ }^{10}$.

Po czwarte, ważną przyczyną, dla której stowarzyszenia regionalistyczne powinny współpracować, jest możliwość modyfikacji wzajemnych zachowań ${ }^{\prime \prime}$. Tu wypada nawiązać do jaźni odzwierciedlonej - koncepcji znanej szczególnie socjologom i antropologom - odnoszącej się do tożsamości jednostek lub grup. Jest dla nas ważne, jak postrzegają nas inni (a precyzyjniej rzecz ujmując - jak uważamy, że nas postrzegają) i na tej podstawie budujemy naszą samoocenę oraz korygujemy własny sposób zachowania. Tak samo jest ze stowarzyszeniami. Jeśli nie będą dysponowały możliwością obserwacji innych organizacji podobnego typu, to prędzej czy później „zdziczeją”, popadną w zacofanie, nieuzasadniony samozachwyt lub dosięgną je inne patologie.

Po piąte, zastanówmy się przez chwilę, kim chcą, lub raczej kim chcieliby być regionaliści w społecznościach lokalnych? Raczej niechętnie określają

Io A. Siciński, dz. cyt., s. 60.

II Por. S. Partycki, Towarzystwa regionalne a rozwój kultury lokalnej, [w:] Być narodowi pożytecznym..., s. 108 . 
się oni mianem teoretyków. Zdecydowanie częściej mówią o sobie, iż są praktykami. To jednak zbyt szerokie ujęcie wymagające doprecyzowania. Tu pomocne są określenia, takie jak: inicjator, animator, ekspert. Zwróćmy uwagę, iż w każdą z tych aktywności wpisana jest kooperacja. W przypadku inicjatora i animatora sprawa jest dość oczywista. Także rola eksperta implikuje porozumiewanie się i współpracę z instytucjami oraz mediami. Regionalista jest ekspertem, zarówno gdy zapraszany jest do radia lub telewizji, do instytucji typu szkoła, muzeum lub uniwersytet, a także gdy występuje jako przedstawiciel stowarzyszenia wnioskującego o grant lub starającego się o zlecenie określonych prac przez instytucję samorządową. Ściślej rzecz ujmując, bycie ekspertem zakłada współpracę z decydentami, którym świadczy się usługi. Ekspert nie istnieje bez określonej klienteli korzystającej z jego usług - opinii, konsultacji, diagnoz, projektów. Regionalista realizuje się jako ekspert szczególnie wówczas, gdy dokonują się w środowisku lokalnym przemiany wymagające intencjonalnego wykorzystania miejscowych tradycji w celu uaktywnienia szerszej grupy mieszkańców dla osiągnięcia określonego celu ${ }^{\mathrm{12}}$. Inicjatorem owych przemian może być np. lokalna władza lub środowisko aktywistów, z którego wywodzi się sam ekspert-regionalista. W ostatnim przypadku możemy mówić o autorytecie wewnątrzśrodowiskowym i dotyczy to zapewne najbardziej doświadczonych i uznanych regionalistów. Podobnie w przypadku działalności inicjującej i animującej, trudno sobie wyobrazić, aby regionalista nie był otwarty na współpracę. Jest ona zatem wpisana w autowizerunek działaczy-społeczników pretendujących do miana animatorów, inicjatorów czy ekspertów. Mirosława Marody, wypowiadając się na temat przyszłości procesów przemian społeczno-kulturowych we współczesnym świecie, przewiduje, że będą one miały dwojaki kierunek. Pojawi się - jej zdaniem - wiele ruchów ponad-i transnarodowych, odcinających się od działań państwa, z drugiej zaś strony, radykalnie wzrośnie znaczenie wspólnot lokalnych i rozwiązywanie wszelkich spraw - od duchowych po egzystencjalne - w ich obrębie ${ }^{13}$. Jeśli przewidywania badaczki się sprawdzą, to regionaliści mają szansę stać się prawdziwymi bohaterami drugiego rodzaju procesów.

Po szóste, współpracę wymuszają na stowarzyszeniach regionalistycznych aktualne warunki formalno-prawne uprawiania działalności. Chodzi

I2 O funkcjach eksperta w warunkach przemian społecznych pisze m.in. J. Goćkowski, Teoretyk i ekspert: role uczestnika przemian spotecznych, [w:] Rozumienie zmian spotecznych, red. E. Hałas, Lublin 2001, s. I85-215.

I3 M. Marody, Spoteczeństwo poobywatelskie?, [w:] Kręgi integracji i rodzaje tożsamości. Polska, Europa, Świat, red. W. Wesołowski, J. Włodarek, Warszawa 2005, s. 218. 
o daleko nieraz idącą profesjonalizację jako warunek pozyskiwania środków oraz realizacji skomplikowanych zadań. Zwracał na to uwagę Jan Jakub Wygnański - teoretyk, a jednocześnie działacz i twórca organizacji pozarządowy ${ }^{14}{ }^{14}$. Profesjonalizować się trzeba, a najskuteczniej, najefektywniej i najtaniej (bo to również ważne) robić to wspólnie, korzystając z własnych doświadczeń. A może regionaliści powinni uparcie nie interesować się takimi zagadnieniami jak profesjonalizacja, czerpiąc radość z przypisywanego im (czasem złośliwie) amatorstwa, które swoją drogą daje czasem więcej radości i satysfakcji niż projektowa kalkulacja? Tak czy inaczej warto o tym podyskutować i przyjąć wspólną strategię.

Wiąże się z tym kolejna kwestia (siódma). Coraz wyraźniejsza staje się potrzeba budowania federacji i rozmaitych problemowych platform umożliwiających skuteczne działania i dających lepszą pozycję wyjściową w relacjach zarówno z sektorem rządowym (samorządowym), jak i prywatnym. To myślenie w kategoriach wspólnotowych wymaga wypracowania dobrego wizerunku publicznego ${ }^{\text {Is. }}$. Trzeba zadać pytanie, czy regionaliści zainteresowani są budowaniem takiego wizerunku? Jeśli tak, to pierwszym krokiem musi być zbudowanie solidnej federacji lub innej reprezentacji środowiska regionalistycznego, która opracuje plan działań w tym zakresie. Jakże byłoby miło i pożytecznie, gdyby regionalizmem zainteresowały się postaci opiniotwórcze, jak to miało miejsce w 20 -leciu międzywojennym. Jednak w dzisiejszych czasach kampanii promocyjnych (także społecznych) i wszechobecnego lobbingu potrzebny jest dobry plan i środki na jego realizację. Współpraca może mieć charakter czysto pragmatyczny. Co za różnica, z jakim stowarzyszeniem wejdziemy w sojusz, gdy będzie chodziło o banalną sprawę skorzystania z tańszych usług księgowego, prawnika lub osoby od pisania wniosków? Może warto się zastanowić nad porozumieniem z innymi towarzystwami i założeniem minifederacji, jeśli nie dla celów ideowych, to choćby tylko dlatego, aby zyskać tańszy dostęp do określonych usług. Zwróćmy też uwagę na zalety tak powszechnej w sferach PR-owskich wymiany barterowej, czyli towar za towar lub usługa za usługę, która przecież dotyczyć może transportu, lokalu, druku, obsługi księgowej, informatycznej itd.

Można by wyliczać kolejne argumenty przemawiające za kooperacją. Poprzestańmy na wymienionych. Prezentowane poniżej porozumienie - choć zawiera wskazania ogólne - samo w sobie posiada walor integracyjny, stanowić może także zapowiedź konkretnych przedsięwzięć. Oby tak się stało.

I4 J.J. Wygnański, Kryzys wzrostu sektora, [w:] Samoorganizacja spoteczeństwa polskiego..., s. 253.

Is P. Marciniak, Trzeciemu sektorowipotrzebna jest ideologia i dobra legislacja, [w:] Samoorganizacja spoteczeństwa polskiego..., s. 134-135. 


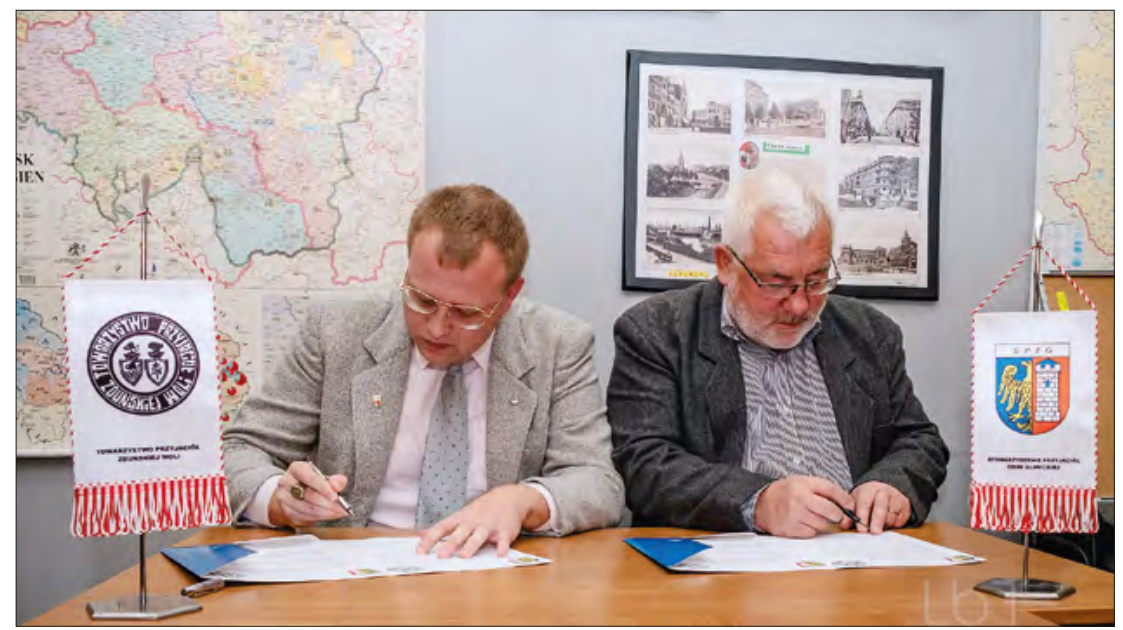

FOT. 2 Porozumienie o współpracy towarzystw regionalnych w Gliwicach i Zduńskiej Woli podpisują Kazimierz Szymański i Jarosław Stulczewski (fot. M. Buksa)

POROZUMIENIE O WSPÓŁPRACY ${ }^{16}$

zawarte w dniu 5 października 2019 r. w Gliwicach pomiędzy: STOWARZYSZENIEM PRZYJACIÓ£ ZIEMI GLIWICKIEJ, Rynek 23, 44-Ioo Gliwice, działającym na podstawie wpisu do Krajowego Rejestru Sądowego nr KRS 0000355998 prowadzonego przez Sąd Rejonowy w Gliwicach, x Wydział Gospodarczy Krajowego Rejestru Sądowego, w imieniu którego działa:

Kazimierz SZYMAŃSKI - prezes Zarządu

a

TOWARZYSTWEM PRZYJACió Z ZDUŃSKIEJ WOli, ul. A. Mickiewicza 4, 98-22o Zduńska Wola, działającym na podstawie wpisu do Krajowego Rejestru Sądowego nr KRS 0000187080 prowadzonego przez Sąd Rejonowy dla Łodzi - Śródmieścia w Łodzi, xx Wydział Gospodarczy Krajowego Rejestru Sądowego, w imieniu którego działa: Jarosław STULCZEWSKI - prezes Zarządu

PREAMBUŁA

Regionalistów zrzeszonych w Stowarzyszeniu Przyjaciół Ziemi Gliwickiej (dalej: SPZG) oraz w Towarzystwie Przyjaciół Zduńskiej Woli

I6 Tekst dostępny na stronie: http://tpzw.pl/?przyjazn-zdunskowolsko-gliwicka-podpisana-5102019,289 [dostęp: 5 czerwca 2020]. 
(dalej: TPZw) łączy długoletnia nieformalna współpraca, a pragnąc ją zacieśnić SPZG i TPZW podpisują porozumienie o wzajemnej współpracy. Szanując autonomię statutów, program, cele i zainteresowania naszych Stowarzyszeń, SPZG i TPZW zawierają niniejsze porozumienie o następującej treści:

I. W celu dalszego wzmocnienia kontaktów, stowarzyszenia podpisują porozumienie o wzajemnej współpracy na rzecz regionów oraz regionalizmu krajowego.

2. Współpraca między SPZG i TPZW obejmuje w szczególności:

- aktywny udział we wspólnych przedsięwzięciach,

- wymianę doświadczeń,

- wspólne prowadzenie projektów,

- wymianę informacji dot. środowiska regionalistów.

3. Za obopólną zgodą Strony mogą zaprosić do współpracy inne podmioty, jeżeli uznają, że jest to zgodne z celami niniejszej umowy i będzie korzystne z punktu widzenia realizacji celów współpracy.

4. Strony zobowiązują się do wzajemnego informowania o podjętych działaniach związanych z ich wspólną działalnością i do wspierania we wszystkich działaniach prowadzących do osiągnięcia celów współpracy.

5. Strony zobowiązują się do umieszczenia informacji o współpracy między Stronami na łamach serwisu internetowego portali internetowych Stron.

6. Porozumienie zostaje zawarte na czas nieokreślony. Każda ze stron porozumienia rezygnując ze współpracy może rozwiązać porozumienie w formie pisemnej z zachowaniem jednomiesięcznego okresu wypowiedzenia bez jakichkolwiek konsekwencji prawno-finansowych. Porozumienie może być zmieniane i uzgadniane za zgodą obu Stowarzyszeń tylko w formie pisemnej, pod rygorem nieważności.

7. Szczegółowe rozwiązania w zakresie współpracy będą uregulowane w odrębnych umowach.

8. Każda ze Stron pokrywa we własnym zakresie wydatki związane z realizacją postanowień Porozumienia.

9. Porozumienie oraz jego realizacja nie mogą naruszać innych obowiązujących przepisów.

ı. Porozumienie wchodzi w życie z dniem podpisania przez Strony.

Ir. Porozumienie sporządzono w dwóch jednobrzmiących egzemplarzach, po jednym dla każdej ze stron. 


\section{Bibliografia}

\section{Opracowania}

Barańska K., Muzea i organizacje pozarządowe. Wposzukiwaniu dobra wspólnego, „Rocznik Muzeum Wsi Mazowieckiej Sierpcu” 2017, t. VIII.

Goćkowski J., Teoretyk i ekspert: role uczestnika przemian spotecznych, [w:] Rozumienie zmian spotecznych, red. E. Hałas, Lublin $200 \mathrm{I}$.

Kalinowski M., Idea spoteczeństwa obywatelskiego a rozwój regionalny, [w:] Rozwój regional$n y-k o n s e k w e n c j e ~ i n t e g r a c j i$, red. A.F. Bocian, Białystok 2005.

Lichwiarz J., Etyka w dziatalności organizacji pozarządowych, „Annales. Etyka w Życiu Gospodarczym" 2011, vol. I4, nr 2.

Marciniak P., Trzeciemu sektorowi potrzebna jest ideologia i dobra legislacja, [w:] Samoorganizacja spoteczeństwa polskiego: trzeci sektor i wspólnoty lokalne w jednoczącej się Polsce, red. P. Gliński, B. Lewenstein, A. Siciński, Warszawa 2002.

Marody M., Spoteczeństwo poobywatelskie?, [w:] Kregi integracji i rodzaje tożsamości. Polska, Europa, Swiat, red. W. Wesołowski, J. Włodarek, Warszawa 2005.

Obracht-Prondzyński C., Cóż regionalistom po samorządach i na cóż w samorzadach regionaliści? Rzecz o zwiazkach oczywistych, koniecznych i zazwyczaj trudnych, [w:] Regionalizm polski 25 lat po transformacji jako ważne źródto odrodzenia narodu i państwa. $x$ Kongres Stowarzyszeń Regionalnych w Bydgoszczy. Referaty i prezentacje. Bydgoszcz II-I3 września 2014 roku, red. J. Derenda, Bydgoszcz 2014.

Partycki S., Towarzystwa regionalne a rozwój kultury lokalnej, [w:] Być narodowi pożytecznym. Dokumentacja VII Kongresu Regionalnych Towarzystw Kultury oraz Pierwszego Walnego Zgromadzenia Ruchu Stowarzyszeń Regionalnych Rzeczypospolitej Polskiej, red. A.J. Omelaniuk, Gorzów Wielkopolski-Wrocław 2002.

Regionalizm polski 25 lat po transformacji jako ważne źródto odrodzenia narodu i państwa. Sprawozdania, wnioski, dokumenty, relacje w mediach, red. J. Derenda, Bydgoszcz 2015.

Siciński A., Rola stowarzyszeń regionalnych w budowaniu spoteczeństwa obywatelskiego, [w:] Być narodowi pożytecznym. Dokumentacja VII Kongresu Regionalnych Towarzystw Kultury oraz Pierwszego Walnego Zgromadzenia Ruchu Stowarzyszeń Regionalnych Rzeczypospolitej Polskiej, red. A.J. Omelaniuk, Gorzów Wielkopolski-Wrocław 2002.

Stulczewski J., Wspótczesna dziatalność Towarzystwa Przyjaciót Zduńskiej Woli-wyzwania i problemy na wybranych przyktadach, [w:] Blisko i daleko. Sympozjum regionalistów - Praszka 2018, red. Z. Szczerbik, Z. Włodarczyk, Wieluń-Praszka 2019.

Woźniak Z., Między rywalizacją a partnerstwem. Bariery wspótpracy wtadz publicznych z organizacjami pozarządowymi, [w:] Samoorganizacja spoteczeństwa polskiego: trzeci sektor i wspólnoty lokalne w jednoczącej się Polsce, red. P. Gliński, B. Lewenstein, A. Siciński, Warszawa 2002.

Wygnański J.J., Kryzys wzrostu sektora, [w:] Samoorganizacja spoteczeństwa polskiego: trzeci sektor i wspólnoty lokalne w jednoczącej się Polsce, red. P. Gliński, B. Lewenstein, A. Siciński, Warszawa 2002.

Zagała Z., Kapitat spoteczny w teorii i praktyce. Więcej pytań niż odpowiedzi, [w:] Kapitat spoteczny, partycypacja spoteczna, rozwój lokalny, red. E. Psyk-Piotrowska, Łódź 2009.

Zdończyk M., Eksperyment bydgoski - partycypacja spoteczna w procesach zarządzania bydgoska kultura, [w:] Regionalizm polski 25 lat po transformacji jako ważne źródto odrodzenia narodu i państwa. $x$ Kongres Stowarzyszeń Regionalnych w Bydgoszczy. Referaty i prezentacje. Bydgoszcz II-I3 września 20I4 roku, red. J. Derenda, Bydgoszcz 2014. 